\title{
Innovativeness of European SMEs: Mission not yet accomplished $^{1}$
}

\author{
DR. HANS RUEDIGER KAUFMANN ${ }^{2}$ \\ DR. HARITINI TSANGAR ${ }^{3}$ \\ PROF. DR. DEMETRIS VRONTIS ${ }^{4}$
}

\section{ARTICLE INFO}

JEL classification: L83, O20, C12,

Keywords:

- European SMEs

- Innovation management

- Corporate culture

- Innovation index

- Multiple regression

\section{ABSTRACT}

Whe paper aims to contribute to the discussion on the catalytic role of SMEs in generating innovation as a basis for a competitive economy. It focuses on six European countries, representing both established and transitional settings (United Kingdom, Cyprus, Spain, Italy, Greece and Lithuania). The statistical methods used included ANCOVA, multiple regression analysis and chi-square tests. The factors explaining the innovation levels were provided. Innovation and corporate culture indices were created and found to be correlated. Four variables were shown to explain innovation management in the six countries: corporate culture, formal processes/innovation department, company size and review of products. The respective SME perceptions, key factors and levels of innovation management were thus differentiated for the six countries. This comprehensive differentiated approach is an innovative contribution to the field.
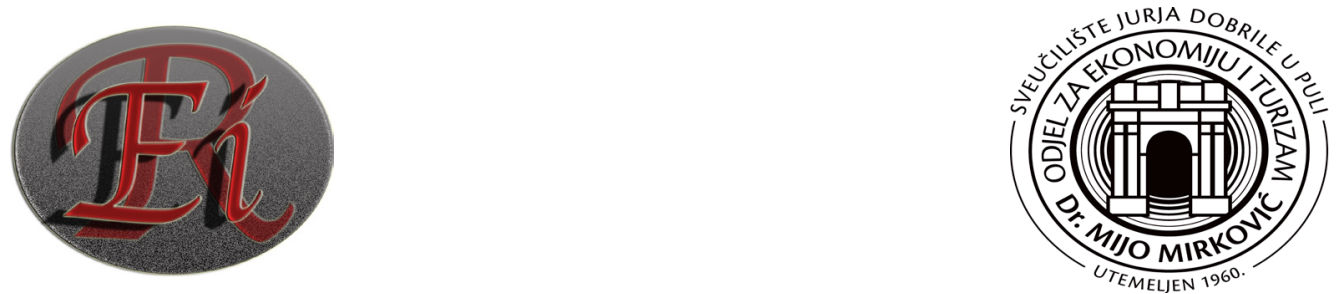

1 "Errata - final and author approved version of the paper replacing the non approved version of paper published in Vol. 25 No. 12012 ”

${ }^{1}$ School of Business, University of Nicosia,Tel: 0035722841643, Email: Kaufmann.r@unic.ac.cy, Fax: + 35722355116 / 353722 ${ }^{2}$ School of Business, University of Nicosia, Tel: 0035722841626, Email: tsangari.h@unic.ac.cy, Fax: + 35722355116 / 
Acknowledgements to the EU Leonardo da Vinci Program, the SMEs participating in this research, Marny Thompson as an academic co-coordinator, and all the other partners who contributed to this project in manifold ways (Grupo CSCS, K.E.K.E.E.E., OEB, Efvet, Atlantis Research Organisation, Marijampole Vocational Education Centre, CECE, Norton Radstock College and Dr. Stelios Mavromoustakos of Intercollege Nicosia)

\section{INTRODUCTION}

In today's globally competitive industry, fresh and original ideas that could generate new technologies, products and services or, even, revolutionize the industry are indispensable stepping stones for economic success, not only for the respective Small and Medium-sized Enterprises (SMEs) but for the European economy as a whole. Accordingly, Jamrog (2006 in Fortuin and Omta, 2009, p.840) points to the "relationship between entrepreneurship, economic growth and poverty reduction". In current research, innovation has been correlated with macro and micro economic objectives such as national or regional competitiveness, profitability and international business success (Geroski et al., 1993; Denton, 1999; Leiponen, 2000; Jones and Tilley, 2003; Lindner, 2006; Franke, 2007). In this context, acronyms like Gold Dust for an efficient economy or backbone and heart of an economy illustratively reflect the significant macro economic contribution of small and medium sized enterprises (SMEs) for economy and society. From a micro perspective, besides the aforementioned profitability increase, Busse and Wallenburg (2011) highlight the contributions of product and service innovation in terms of creating revenues, cost savings and improved processes (Khazanchi et al., 2007, in Busse and Wallenburg, 2011) as well as being a potential source of competitive advantage (Dougherty and Hardy, 1996; McGrath and Ming-Hone, 1996, in Busse and Wallenburg, 2011). Indeed, it is this competitive advantage which will guarantee SMEs' survival as indicated by Christensen (2006) and Elonnen, Blomqvist and Puumalainen (2008) stressing with a sense of urgency that companies will not survive unless they have the ability to continuously renew and innovate. Furthermore, innovation can be seen as a kind of protective shield for SMEs as explained by Nicholas, Ledwith and Perks (2011, p.227): "companies must innovate in order to expand into new markets, to arrest margin erosion and to protect their current market share".

Against this background, it appeared to be an interesting research aim to investigate if different levels and factors of innovation management in SMEs in a variety of European settings exist. The main motivation and focus of this research was to provide differentiated factors that explain innovation management in six European countries in order to inform innovation strategies of both, entrepreneurs and macro decision makers of the European Union (EU). To the knowledge of the authors, no European cross-country research exists in current literature explaining the innovation levels of the respective countries. Innovatively, the research allows also, albeit to a limited extent, for a comparison between 'established' European and 'transitional' European settings. The quantitative methodology applied including descriptive statistics, Chi-square $\left(\mathrm{X}^{2}\right)$ tests of independence, Analysis of Covariance (ANCOVA) and multiple regression analysis, has provided the advantage of differentiating the respective SME perceptions, key factors and levels of innovation management. This is a contribution to the field and gives new 
insight into the discussion regarding the catalytic role of SMEs in generating innovation as a basis for a competitive economy and the effective interplay between macro decision makers and entrepreneurs. The main more detailed research problems addressed by this research relate to the hypothesized and confirmed lack of entrepreneurial perception of innovation as a strategic, systematic approach, the importance of corporate culture for innovation and still existing external and internal barriers for innovation. The research findings provide a number of suggestions for entrepreneurs, teachers and macro decision makers culminating in the demand for more concerted actions between entrepreneurs, universities and government. The research represents an integral part of the MINT project (2008-2009), which was supported by the LEONARDO program of the EU.

The paper sets out with the role of entrepreneurial innovation as being a bridge between macro and micro perspectives and objectives reflecting the necessary interest of both sides in an effective innovation system. This discussion is followed by the key tenet of the paper in that entrepreneurial innovation should be regarded as systematically planned rather than ad hoc approach implying to integrate a range of management disciplines. Regarding management disciplines, emphasis is placed on corporate culture driven by transformational leadership as the very heart and motor of innovation management. Finally, potential external and internal barriers to innovation management are addressed with the key conceptual construct finalizing the literature review. Consecutively, the research objectives, methodology, discussion of findings, implications for practice and suggestions for further research are presented.

\section{THEORY BACKGROUND}

\section{A. Innovation: Bridging Macro and Micro Perspectives}

According to the European Commission (2003, in Nicholas, Ledwith and Perks, 2011), SMEs represent $99 \%$ of the total enterprises, and innovative abilities of SMEs are correlated with the recovery and the continued development of European economies.

Increasing corporate, national or regional competitiveness is regarded a key objective for economic policy (Martin, n.d.; The European Central Bank). Confirming the role of SMEs in this respect, Oke, Burke and Myers (2007, p.735) emphasize that "the governments of most developed economies see new and smaller enterprises as the well-spring of economic growth and job and wealth creation". Hence, as innovation is regarded to be a conditional factor for competitiveness (Denton, 1999), research in this field informs macro-economic strategies.

In more detail, the relationship between macro-economic aspects as, for example, needs of society and market place, technological developments, tax issues and innovation created by entrepreneurship has been established in literature (Choueke and Armstrong, 1998; Darroch and McNaughton, 2002; Shaw, O'Loughlin, and McFadzean, 2005; Wolff and Pett, 2006; Oke.et al, 2007). Relating technological developments as a cornerstone for innovation with consumer orientation, Jantunen (2005, p.338) explained that "rapid technological change and changing customers' preferences mean that the continuous introduction of product improvements and the development of new products is imperative for firms". Continuing with the micro 
perspective, innovation has been linked to marketing and consumer orientation in general (Weerawardena, 2003; Drucker, 1954 in O’Dwyer et al., 2009; Neira et al., 2009), as well as to marketing behaviors of SMEs in particular (Morris and Lewis, 1995 and Sexton and Arbaugh, 1992, in: O’Dwyer et al., 2009). In the same vein, Jamrog (2006, in Fortuin and Omta, 2009, p.840) focuses on issues like "identified customer centricity, teamwork, appropriate resources, organizational communication, the ability to select the right ideas and freedom to innovate" as being crucial for companies' innovation activity.

Achieving these macro-economic and micro-economic objectives necessitates a particular mindset of entrepreneurs. According to Morris and Sexton (1996, in Chowdhury, 2007, p.240) core entrepreneurial characteristics relate to "innovativeness, calculated risk-taking and proactiveness". In addition to innovativeness, the Classical School of Entrepreneurship associates entrepreneurial characteristics with creativity and discovery (Cunningham and Lischeron in Koh, 1996). The definition of innovation of entrepreneurship by the Commission of the European Communities (2003, p. 6 in Klapper, 2004, p. 128) adds a managerial perspective: "the mindset and process to create and develop economic activity by blending risk-taking, creativity and/or innovation with sound management, within a new or an existing organization".

These characteristics crystallize the central contribution of entrepreneurs in playing a an optimizing agent exploiting market related or social imbalances and gaps and transforming them into market opportunities (O’Dwyer et al., 2009; Boyett, 1997 in Kaufmann, 2009). In this sense, entrepreneurs are innovative 'bridge builders' between macro-and microperspectives referring, for example, to overcoming currently existing macro problems such as public budget constraints for social purposes (Kaufmann, Mewaldt and Sanchez Bengoa, 2012), integrating economically marginalized rural areas into the global stream of business, overcoming industry segment problems in certain areas (e.g. textile, tourism, or agriculture), or providing for diversification and differentiation of products and services (Kaufmann, 2009). Beyond the aforementioned SME contribution to the economy, Henderson, (2002 in Oke, Burke and Myers 2007) confirms the SMEs' important role to connect the local community to the larger global economy.

Conclusively, knowledge on the detailed differentiated factors which foster innovation in European countries is of paramount interest for both, entrepreneurs and macro-economic decision makers alike to concertedly create an infrastructure and educational system supporting, fostering and encouraging effective entrepreneurship.

\section{B. Innovation: Systematically Planned Based on Corporate Culture}

At this stage, the important question arises of how to best generate innovation in companies as well as societies. De Jong and Den Hartog, (2007, p.41) suggest "to capitalize on their employees' ability to innovate" implying an appropriate innovation culture and programs to maximize efficiency. Central to innovation program designs is a disciplined, systematic and planned approach (Boer et al, 1990) compared to a process being perceived as natural or ad hoc (Amabile et al., 2002 in McAdam et al, 2007). Referring to Hyland and Beckett (2005), McAdam et al. (2010, p. 198-199) hold that "innovation can be treated as a process that systematically interacts with all organizational processes and product development" and 
propose an innovation implementation model for SMEs. Previous research implies that a key shortcoming of entrepreneurial characteristics and skills refers to a strategy implementation gap (i.e. EU, 2005; Kaufmann, 2008; Crick, 2011). This gap could be explained in that systematic planning behavior might be inconsistent with anti-systemic features of entrepreneurs (Berglund and Johansson, 2007). Furthermore, this systematic process might be perceived as difficult and complex, due to its multidimensional character (Zhao, 2005; Neira et al., 2009) requiring to utilize and embrace the complete management discipline (Antonakis, 2006) including:

\section{TABLE 1: Managerial Disciplines for Successful Innovation}

\begin{tabular}{|c|c|}
\hline Discipline & Author/s \\
\hline Change management & Damanpour (1991) \\
\hline Organizational learning & Wyer et al. (2000) \\
\hline Action learning by SMEs & Choueke and Armstrong (1998) \\
\hline Work organization systems & Weerawardena (2003) \\
\hline $\begin{array}{l}\text { Corporate culture (i.e. decision making pat- } \\
\text { terns, teamwork, 'open culture', leadership, } \\
\text { i.e. empowerment) }\end{array}$ & $\begin{array}{l}\text { Burpitt and Bigoness (1997); Hurley and Hult } \\
\text { (1998); Prajogo and Sohal (2003); Antonakis, (2006); } \\
\text { Barsh et al. (2008) }\end{array}$ \\
\hline $\begin{array}{l}\text { Mergers \& acquisition (towards synergistic } \\
\text { combination of resources) }\end{array}$ & Christensen (2006) \\
\hline $\begin{array}{l}\text { Knowledge acquisition, creation and dissemi- } \\
\text { nation, knowledge management } \\
\text { Resource Management, Finance }\end{array}$ & $\begin{array}{l}\text { Du Plessis (2007), Cohen and Levinthal (1990), } \\
\text { Chesbrough (2003), Jantunen (2005) } \\
\text { (Freel, 2000, Vossen, 1999, and Tidd et al., in Mc- } \\
\text { Adam et al. (2010) }\end{array}$ \\
\hline Marketing & Banterle et al. (2009) \\
\hline
\end{tabular}

SOURCE: developed by the researchers

Problems with complexity issues as to innovation are mentioned in a study by Deloitte Touche Tohmatsu (2003). Relating to structuring manufacturing companies for innovation in an overall supply chain context, the authors coined the phrase of 'innovation paradox" reflected by the following quote: "While manufacturers say product innovation is their top priority for driving revenue growth, it ranks last on the supply chain agenda. Time-to-market is second to last, another sign that many manufacturers' factories and logistics operations aren't prepared for a world of rapid product changes" (http://www.deloitte.com/assets/DcomShared\%20 Assets/Documents/SupplyChainSurvey(1).pdf).

Referring the latter study specifically to SMEs, Baard and Watts (2007) reject the view that this phenomenon is of contemporary nature only and found evidence, based on a case study of a small manufacturer, that the 'innovation paradox' did not apply to this SME.

Implying the salient importance of corporate culture for innovation success, sustained innovativeness is regarded to depend on each firm's set of dynamic capabilities, which helps it "integrate, build, and reconfigure internal and external competencies to address rapidly changing environments" (Teece et al., 1997, p. 516). In this context, Morcillo (1997) relates a culture of innovation to values and attitudes to increase the efficiency of operations even if they break the traditional or conventional routine. Especially, Corporate Culture might be 
regarded as the basis for an innovation strategy which requires newly acquired or transformed capabilities implying a focus on human capital development (Branzei and Vertinsky, 2006). On the other hand, other innovation strategies, such as process, product or market development can be based on the integration of existing capabilities i.e. via research, market intelligence, assimilation or deployment (Ostgaard and Birley, 1994, Bierly and Chakrabarti, 1996, Helfat and Raubitschek, 2000, Winter and Szulanski, 2001, Zahra and George, 2002, in Branzei and Vertinsky, 2006).

Summarizing, the relationship between competitive advantage, innovation, marketing strategy, and distinctive and hard-to-imitate resources and skills is indicated by AragónSánchez' and Sánchez-Marín's (2005) view. These authors regard a distinctive advantage to have any recognizable strategic value to be more and more linked to intangible assets such as innovation and technology. The composition and intensity of these assets depend on the chosen strategic positioning. To strategically best utilize innovation as an intangible asset, still existing internal and external barriers and ways to overcome them are discussed in the next paragraph.

\section{Innovation Barriers and Remedies}

Challenges related to innovation management are provided by a variety of internal and external factors. According to Demirbas, Hussain and Matlay (2011, p.765), "the external environment both influences and limits the innovative capacity in SMEs and disadvantages owner-managers in terms of their competitive strategy vis-à-vis larger firms". In this context, a series of external factors have been identified as limiting the SMEs's innovation capability: "government regulations or policy actions not being conducive to innovation, lack of access to funding, weak contract enforcement, or less developed local labor markets, networks and relationships or knowledge networks" (Rothwell, 1989, Lange et al., 2000, Blundel and Hingley, 2001, Keizer et al., 2002, Bougrain and Haudeville, 2002, NESTA, 2008a, b, 2009 in Hotho and Champion 2011, p. 32). Referring to an international context, Cooney and O'Connor's (1996 in Demirbas, Hussain and Matlay, 2011) as well as Keegan et al's. (1997 in Demirbas, Hussain and Matlay, 2011) work implies to conduct more country specific as well as crosscountry research so as to determine which barriers are country specific and which ones are commonly identified across industrially developed or developing countries.

The European Commission puts efforts to overcome regulatory uncertainties, still stubbornly high remaining telecommunications costs, and a continuing lag behind the US in terms of venture capital. Therefore, web-based resources are provided to disseminate information to SMEs in order to enhance their competitive position and increase the level of innovativeness (Peet et al., 2002).

Relating back to the management disciplines affecting innovation as discussed in the previous paragraph, Delahaye, (2005 in Hotho and Champion, 2011) and Segarra-Blasco et al. (2008 in Demirbas, Hussain and Matlay, 2011) identified the following internal barriers: ownermanager's ability to identify, evaluate and access relevant technological information, expert skills, time, internal funds, but also knowledge systems or organizational variables including structures, cultures, norms and leadership (Tidd et al., 2001, Keizer et al., 2002, McAdam et 
al., 2004, O’Regan et al., 2005, Demirbas et al, 2011 in Hotho and Champion, 2011, p.32), and finally "the absence of a formal innovation strategy and excessive administrative regulations to be the greatest barriers to innovation success" (Jamorog, 2006 in Fortuin and Omta 2009, p.840). Regarding internal barriers, Forman and Rantanen (2011) referring to Cohen and Klepper (1996a), Hannula and Rantanen (2000), Scozzi et al. (2005) and Forsman (2008), SMEs seem to lack the ability to
a. identify opportunities
b. track current market and technology trends
c. properly manage knowledge
d. assess the influence of development work on the company's business
e. develop proactive attitudes towards innovation and
f. successfully engage in networking.

As innovations trigger fundamental organizational changes leading to the formation of new patterns of corporate and individual behavior (Morcillo, Rodriguez-Anton, Rubio, 2006), a major internal innovation hurdle is hypothesized to exist in a corporate culture which is resistant to change and adaptation. The crucial role of corporate culture in innovation driven change processes is indicated by Kotter and Hesket (1992, in Morcillo, Rodriguez-Anton, Rubio, 2006, p.350): "As a result, the destabilizing effect of innovation will always depend on the adaptive or non-adaptive nature of the cultural models applied within an organization". Another important issue regarding innovativeness of SMEs, which embraces both external and internal perspectives, arises in the context of intellectual property protection and patents. According to Hughes and Mina (2010), occurring costs, which are higher compared to those of large firms, might prevent the use of patents in SMEs. Acknowledging progress having been made, Europe's small businesses called for a single European Community patent to be a top priority to boost innovativeness. Consequently, "the European Commission's new overview of innovation policy includes plans for a European Innovation Act” (European Union, 2011). Summarizing, the significant investment needed to find, develop and materialize a creative idea is regarded another challenging innovation hurdle for many SMEs. Although, SMEs may have a high potential for creativity and innovativeness, they may lack the necessary finances hampering their development as discussed before. In order to address this balance, the European Commission, the European Investment Bank and the European Investment Fund have generated schemes to support innovation within SMEs. The main funding opportunities available for European SME's are (InnoSupport, 2011): • Grants • Venture capital • Banks • Stock markets • Business angels.

Taking these funding mechanisms and the generally accepted contribution of innovation to macro and micro competitiveness into account, this research intends to answer the question to what extent European SMEs are utilizing these schemes and to what extent other internal and external stumbling blocks are still existing. Furthermore, the research intends to differentiate the respective factors affecting innovation by 6 different European countries and by 'established' European settings and 'transitional' European settings.

To the knowledge of the authors, existing innovation management related studies on SMEs mainly exist for individual member states (i.e. Oke et al., 2007; Salavou and Avlonitis, 2008; Radzeviciene, 2008). Accordingly, the main aim of this study was to identify differentiated factors affecting innovation and explaining different innovation levels of European SMEs. 
Reflecting the previous text, the following key research construct (Figure 1) guided the empirical research.

\section{INNOVATION: BRIDGING MACRO- AND MICRO-PERSPECTIVES}

\section{FIGURE 1}

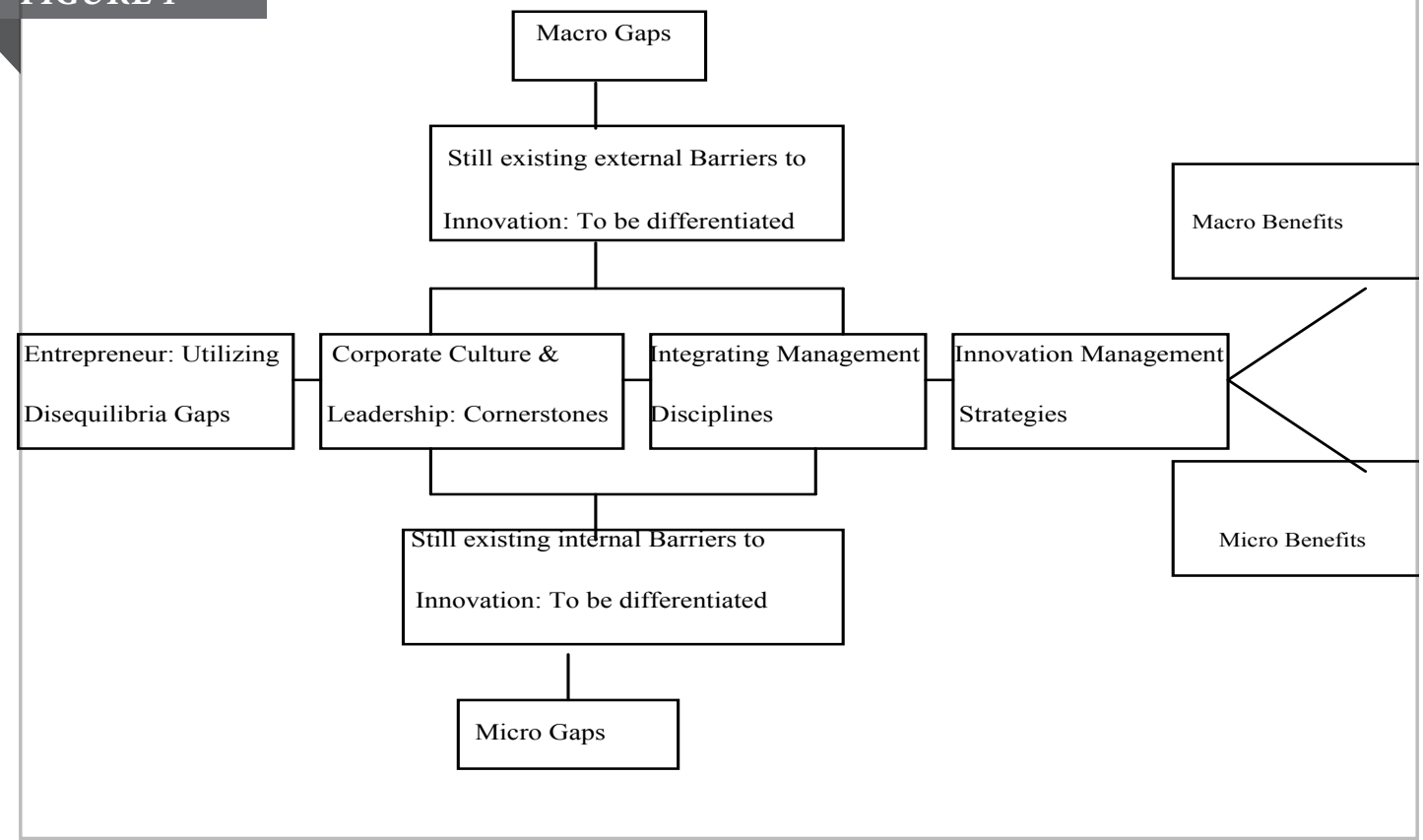

SOURCE: author

\section{RESEARCH OBJECTIVES}

The research objectives of this study were to investigate still existing hurdles for innovation and the level of systematic application of different management functions relevant for innovation management in European SMEs. More specifically, the objectives of the study were to investigate if there exist cross-country differences in the levels of innovativeness of European SMEs, the extent to which companies pursue innovation as a strategic approach, the factors companies employ to encourage innovation, the factors which block innovation and the perceived level of innovation support by other institutions, agencies and companies. This information can be used as reference, as to whether factors of innovation management approaches have to be differentiated according to the different European countries. The hypotheses for the research were:

1. There are different innovation levels of SMEs in the selected European countries. 
2. European SMEs do not perceive innovation management as a systematic process.

3. There is a relationship between corporate culture and innovation management in European SMEs.

4. The factors that explain innovation hurdles have to be differentiated as to the different European countries.

\section{A. Design and Sample}

Representing an integral part of the 2 years (2008-2009) lasting MINT project (http://www. mintproject.org/), a consortium of six partners from 6 European companies was selected to investigate these research objectives. The mix of partners coming from academic and professional education institutions with partners from agencies/consultancies provided a very good basis for an action research approach.

Quantitative data were collected using a questionnaire that was specifically designed to address the research questions of the study, after in-depth examination of the literature in order to theoretically underpin the empirical stage and ensure its content validity. The questionnaire was pre-tested with 10 SMEs and an incubation center in England and Cyprus. The final version of the questionnaire was distributed to SMEs in Cyprus, England, Greece, Italy, Lithuania and Spain. Greece was divided in two parts, Athens (which is in the south part of the country, closer to the Mediterranean sea) and Thessaloniki (closer to Central Europe). The questionnaires were personally administered to the companies by the partners of the project.

The final sample included 204 questionnaires. More specifically, 30 companies were selected from Italy (14.7\%), 30 from England (14.7\%), 23 from Greece (Thessaloniki) (11.3\%), 33 from Greece (Athens) (16.2\%), 30 from Cyprus (14.7\%), 30 from Lithuania (14.7\%), and 28 from Spain (13.7\%). The respondent in each company was either Owner, or Owner/Manager, or Senior Manager, or other manager or employee in the company.

\section{B. Data analysis}

The data were analyzed using the statistical software package SPSS. Various statistical methods were used to test the hypotheses of interest, including descriptives statistics, Chi-square $\left(\mathrm{X}^{2}\right)$ tests of independence, Analysis of Covariance (ANCOVA) and multiple regression analysis. 


\section{FINDINGS OF THE STUDY}

\section{A. Respondents' profiles and company characteristics}

Company profiles of the participating European SMEs in the sample were examined, in relation to the size (number of employees), type of company (public or private), location of business and type of industry. Table 1 provides profile information about the companies in the overall sample and per country separately.

TABLE 1: Information about company profiles

\begin{tabular}{|c|c|c|c|c|c|c|c|}
\hline $\begin{array}{l}\text { Italy } \\
\%\end{array}$ & $\begin{array}{l}\text { England } \\
\%\end{array}$ & $\begin{array}{l}\text { Greece } \\
\text { (Thes.) } \\
\%\end{array}$ & $\begin{array}{l}\text { Greece } \\
\text { (Ath.) } \\
\%\end{array}$ & $\begin{array}{l}\text { Cyprus } \\
\%\end{array}$ & $\begin{array}{l}\text { Lithuania } \\
\%\end{array}$ & $\begin{array}{l}\text { Spain } \\
\%\end{array}$ & $\begin{array}{l}\text { Total } \\
\%\end{array}$ \\
\hline
\end{tabular}

Number of employees

Under 10

11-49

$50-250$

More than 250

Type of company

Public

Private

Place of business

\begin{tabular}{|c|c|c|c|c|c|c|c|c|}
\hline $\begin{array}{l}\text { a) Village (up to } 2000 \\
\text { residents) }\end{array}$ & 13.3 & 35.7 & - & - & 3.3 & 3.3 & - & 7.9 \\
\hline $\begin{array}{l}\text { b) Town (2001-20000 } \\
\text { residents) }\end{array}$ & 30.0 & 42.9 & 4.3 & - & 26.7 & 23.3 & 3.6 & 18.8 \\
\hline $\begin{array}{l}\text { c) Small city ( } 20001 \text { - } \\
100000 \text { residents) } \\
\text { d) City (more than }\end{array}$ & 36.7 & 3.6 & 4.3 & - & 43.3 & 70.0 & 14.3 & 25.2 \\
\hline 100000 residents) & 20.0 & 17.9 & 91.3 & 100.0 & 26.7 & 3.3 & 82.1 & 48.0 \\
\hline \multicolumn{9}{|l|}{ Type of industry } \\
\hline Tourism & - & 3.6 & 9.5 & 6.1 & - & 3.3 & 7.1 & 4.0 \\
\hline Retail & 7.1 & 14.3 & - & 9.1 & 20.0 & 26.7 & - & 11.6 \\
\hline Engineering & 3.6 & 7.1 & 9.5 & - & 10.0 & 10.0 & - & 5.6 \\
\hline Automotive & 10.7 & 17.9 & - & 6.1 & 6.7 & - & 3.6 & 6.6 \\
\hline Telecom & 3.6 & 3.6 & - & - & 3.3 & 10.0 & 3.6 & 3.5 \\
\hline Health & - & - & 4.8 & 6.1 & - & - & 3.6 & 2.0 \\
\hline Construction & - & 3.6 & 4.8 & 3.0 & 10.0 & 13.3 & - & 5.1 \\
\hline Manufacturing & - & 3.6 & - & 3.0 & 6.7 & 3.3 & - & 2.5 \\
\hline Research & 25.0 & 3.6 & - & - & - & 3.3 & 14.3 & 6.6 \\
\hline Consulting & 17.9 & - & 9.5 & 3.0 & - & - & 3.6 & 4.5 \\
\hline Services general & - & 3.6 & 19.0 & 3.0 & - & 3.3 & 35.7 & 8.6 \\
\hline \multirow[t]{2}{*}{ Other } & 10.7 & 10.7 & 9.5 & 9.1 & 30.0 & 10.0 & 3.6 & 12.1 \\
\hline & 21.4 & 28.6 & 33.3 & 51.5 & 13.3 & 16.7 & 25.0 & 27.3 \\
\hline
\end{tabular}

SOURCE: Author

$\begin{array}{llllllll}63.3 & 44.8 & 73.9 & 42.4 & 46.7 & 33.3 & 39.3 & 48.3 \\ 26.7 & 13.8 & 26.1 & 57.6 & 53.3 & 53.3 & 14.3 & 36.0 \\ 6.7 & 27.6 & - & - & - & - & - & 9.4 \\ 3.3 & 13.8 & - & - & - & - & - & 6.4\end{array}$

- 29.6

$100 \quad 70.4$

$\begin{array}{ll}3.0 & 10.0\end{array}$

16.7

$3.6 \quad 9.0$

$96.4 \quad 91.0$

$\begin{array}{llllll}- & 3.0 & 10.0 & 16.7 & 3.6 & 9.0 \\ 100.0 & 97.0 & 90.0 & 83.3 & 96.4 & 91.0\end{array}$




\section{B. Cross-country differences in innovation levels}

An index of innovation was created, using items 7 (New products/services in last 2 years), 8 (Social innovations in last 2 years), 9 (Process innovations in last 2 years), 14 (Number of patents registered in last 2 years). These items were originally rated on a 4-point scale (none, $1,2-4,5-10$ and more than 10). The questions were recoded accordingly, so that low values showed a low degree of innovation and high values of the index showed that the company has a high level of innovation. The respondents' answers were averaged so that the index ranged continuously from 0 to 4 , where zero shows no innovation.

Before examining cross-country differences in innovation levels, the respondents' profiles in the sample were examined, in order to see if any adjustments were necessary. Chi-square tests showed that indeed the respondents had significant cross-country differences in terms of their position in the company $(\mathrm{p}<0.001)$, gender $(\mathrm{p}<0.001)$, age $(\mathrm{p}=0.04)$, level of education $(\mathrm{p}<0.001)$ and familiarity with innovation processes $(\mathrm{p}=0.004)$. In addition, a Chi-square $\left(\mathrm{X}^{2}\right)$ test showed that cross-country differences existed in relation to the size of the SMEs (p-value<0.001). Therefore, the innovation index means were adjusted so that the respondents' profiles and the size of the SMEs in each country would not affect the results, and that samples were made comparable. Marginal means were estimated for each country, along with $95 \%$ confidence intervals. An Analysis of Covariance (ANCOVA) F-test for cross-country comparisons of the innovation level was performed, where the covariates were the aforementioned demographic characteristics of respondents and the size of the companies. Confirming hypothesis 1 , the results showed significant country differences in terms of innovation ( $F=3.881, p=0.001)$, where Cyprus had the highest level of innovation and Spain had the lowest. All the results regarding cross-country differences in innovation levels appear in Table 2.

TABLE 2: Estimated marginal means, confidence intervals, ANCOVA results (F-Statistic, degrees of freedom, p-value), for cross-country comparisons for innovation- adjusted for respondents' profile and size of SME.

\begin{tabular}{lllllll} 
Country & $\mathrm{n}$ & Mean & $\begin{array}{l}\text { Lower } \\
\text { Bound } \\
\text { of 95\% CI }\end{array}$ & $\begin{array}{l}\text { Upper Bound } \\
\text { of 95\% CI }\end{array}$ & p-value \\
\hline Italy & 30 & 1.358 & 1.097 & 1.618 & \\
England & 30 & 1.265 & 1.023 & 1.507 & & \\
Greece (Thessaloniki) & 23 & 1.466 & 1.174 & 1.757 & & \\
Greece (Athens) & 33 & 1.135 & .917 & 1.354 & $3.881(6)$ & 0.001 \\
Cyprus & 30 & 1.561 & 1.330 & 1.793 & & \\
Lithuania & 30 & 1.444 & 1.209 & 1.680 & & \\
Spain & 28 & 0.801 & .529 & 1.073 & & \\
Total & 204 & 1.290 & 1.204 & 1.377 & & \\
\hline
\end{tabular}

SOURCE: Author

Examination of the individual items that constitute the innovation index provided additional intuition to the results. More specifically, the results showed that the highest level of product/ service innovations were achieved in Cyprus, Greece (Thessaloniki) and Lithuania. However, a relatively high percentage (around 30\%) of SMEs in Cyprus, Italy and Spain did not generate 
any product/service innovation in the last two years. Similar or higher percentages of no social and process innovations were also observed in these countries.

The highest level of patent registrations was observed in Cyprus, followed by Spain and Italy. However, the vast majority of $91.7 \%$ did not register a patent in the last 2 years, with Lithuania not achieving a single patent registration. Whereas England confirms the general trend of this deplorable state of patent registrations, a small number of companies (3.3\%) achieved more than 10 registrations in the last two years. Chi-square tests revealed that significant crosscountry differences existed regarding how long it takes for the introduction of new products to the market, where the quickest 'introducers' are Cyprus, England and Italy with Spain, Lithuania and Greece being the slowest ones $(\mathrm{p}<0.001)$. Whereas $77.3 \%$ of the respondents need only up to one year for product/service introduction, $22.8 \%$ need 2 or more years. A lack of strategic approach as to innovations is reflected in that almost $34 \%$ of the companies do not state innovation in its corporate strategy with Cyprus negatively heading the list (70\%) $(\mathrm{p}<0.001)$.

Moreover, $50.5 \%$ of all companies introduce the products quicker than the competitors (first to market strategy). Significant cross-country differences existed $(\mathrm{p}=0.003)$, where especially Cyprus (30\%) followed by Lithuania (27.6\%) lag behind competitors in terms of speed of product introduction. Around $29 \%$ of all companies do not quickly integrate social changes or tendencies. Significant cross-country differences exist, with Spanish SMEs being the least open $(66.7 \%)$ to this very important factor of the external business environment $(p=0.002)$. Confirming hypothesis 2, the lack of strategic approaches as to innovation is highlighted by a lack of innovation department or formal innovation processes stated by $73.6 \%$ of all companies, with no significant cross-country differences $(\mathrm{p}=0.621) .64 .7 \%$ of all companies are innovating organically. Cross-country differences exist $(\mathrm{p}<0.001)$, with England having the highest percentage of organically innovating companies (86.2\%), and Lithuania the lowest (23.3\%).

Better technology, new market opportunities and customers' requirements are perceived by all companies as reasons for improvements. Minimizing waste, cost reduction and, especially, suppliers' suggestions are less considered reasons for improvements. Taking the generally accepted importance of customer orientation into account, it is astonishing that customer requirements are only considered to a very low extent as reasons for improvements in Italy, Greece (Athens) and Spain. 83.6\% of all SMEs perceived the improvements as having been successful measured by financial gains (43.5\%) and increased market position (40.1\%).

\section{Cross-country differences in Corporate Culture}

An index of corporate culture was created based on questions 20 (Your company empowers employees to actively contribute to innovation), 21 (if managers/senior employees/employees participate in new ideas), 23 (if you are not the owner do you feel you have influence on new product or service development), 25 (is the corporate culture supportive of innovation) and 28 (Do you perceive resistance to change?). The questions were recoded accordingly, so that low values showed a low degree of corporate culture and high values of the index showed that the company has a high level of corporate culture. The respondents' answers were averaged so 
that the index ranged continuously from 0 tol, where zero shows no corporate culture at all. Descriptive statistics for the corporate culture index appear in Table 3.

TABLE 3: Descriptive statistics for corporate culture index

\begin{tabular}{lllll}
\multicolumn{1}{c}{ Country } & Mean & Std. Deviation & Minimum & Maximum \\
\hline Italy & .6458 & .16517 & .33 & .83 \\
England & .7685 & .20721 & .33 & 1.00 \\
Greece/Thessaloniki & .5833 & .23570 & .17 & .83 \\
Greece/Athens & .6667 & .34960 & .17 & 1.00 \\
Cyprus & .5370 & .41443 & .00 & 1.00 \\
Lithuania & .7308 & .24073 & .17 & 1.00 \\
Spain & .6250 & .28549 & .00 & 1.00 \\
Total & .6619 & .28770 & .00 & 1.00 \\
\hline
\end{tabular}

SOURCE: Author

Cross-country statistical comparisons were performed on corporate culture index, using ANCOVA to adjust for the respondents' profiles and companies' size, in order to have comparable samples. Results showed that no significant differences in corporate culture existed between the countries $(\mathrm{F}=1.507$, $\mathrm{p}$-value $=0.185)$. Results on the total sample showed that around $25 \%$ of SMEs do not empower employees to actively contribute to innovation. Also, around $27.3 \%$ of all respondents, of those who are not the owner, do not perceive an influence on new product and service development. In the majority of cases, new product ideas come from owners, especially in Cyprus, Italy and Greece (Thessaloniki). The paramount role of the customer as well as the supplier for product idea provision is mostly acknowledged only by Cyprus and England. Interestingly and encouragingly, in most of the cases across all countries 'any employee' is integrated in product/service idea selection and screening, especially in Greece (Thessaloniki), Lithuania and England. Again, customers and suppliers are less considered in this respect.

Most companies (77.1\%) regard their employees as skilled in product/service development or creativity, and no cross-country differences existed ( $\mathrm{p}$-value $=0.613$ ). Also, corporate culture is regarded by the vast majority of respondents $(82.6 \%)$ as supportive for innovation, and no cross-country differences existed ( $\mathrm{p}$-value $=0.330$ ). In those cases, where corporate culture was not regarded as conducive to innovation, the main reasons for that were lack of necessary resources (49\%), lack of preparedness to take risks (42.9\%) and lack of innovation training for employees (28.6\%).

\section{The relationship between Corporate Culture and Innovation}

Correlation analysis was performed, in order to examine the relation between corporate culture innovation and innovation level (hypothesis 3 ). The Pearson correlation coefficient was calculated between the two indices, both, for the total sample and for each country separately. Results showed that a positive relationship existed between the two indices for the total sample $(\mathrm{r}=0.494, \mathrm{p}<0.001)$, indicating that the higher the corporate culture level, the higher 
the innovation level. When examining the relation for each country separately, the relation between corporate culture and innovation was significant for Cyprus $(r=0.885, p<0.001)$ and Lithuania $(\mathrm{r}=0.490, \mathrm{p}=0.011)$. There was no relation between the two indices for Italy $(\mathrm{r}=0.354$, $\mathrm{p}=0.437)$, England $(\mathrm{r}=0.217, \mathrm{p}=0.403)$, Greece $(\mathrm{r}=0.431, \mathrm{p}=0.334$ for Thessaloniki and $\mathrm{r}=0.531$, $\mathrm{p}=0.278$ for Athens) and Spain $(\mathrm{r}=0.089, \mathrm{p}=0.710)$.

\section{E. Factors that significantly affect innovation}

In an attempt to identify which factors significantly lead to successful/unsuccessful innovation, a stepwise multiple regression analysis was performed, with dependent variable the innovation index and independent variables the key items of the questionnaire. The results regarding the total sample appear in Table 4.

TABLE 4: Stepwise Multiple Regression for innovation: all countries together

\begin{tabular}{|c|c|c|c|c|c|c|c|}
\hline & B & $\begin{array}{l}\text { Stand. Coef- } \\
\text { ficient }\end{array}$ & $\mathrm{T}$ & p-value & $\begin{array}{l}\mathrm{R} \\
\text { Square }\end{array}$ & $\begin{array}{l}\text { Adj. R } \\
\text { Square }\end{array}$ & $\begin{array}{l}\text { R Square } \\
\text { Change }\end{array}$ \\
\hline (Constant) & 1.603 & & 3.429 & .001 & & & \\
\hline Culture index & 1.028 & .349 & 4.299 & $<.001$ & .368 & .359 & .368 \\
\hline $\begin{array}{l}\text { Department or } \\
\text { formal process }\end{array}$ & -.525 & -.263 & -3.144 & .002 & .521 & .508 & .153 \\
\hline Company Size & .311 & .291 & 3.692 & $<.001$ & .594 & .576 & .072 \\
\hline $\begin{array}{l}\text { Review of existing } \\
\text { products }\end{array}$ & -.443 & -.238 & -2.981 & .004 & .639 & .619 & .046 \\
\hline
\end{tabular}

SOURCE: Author

The results showed that the factors that significantly lead to successful innovation, in order of importance (as indicated by Rsquare change), are: 1) Corporate culture ( $b=1.028, p=0.001)$, where the positive coefficient shows that when corporate culture index increases by 1 unit, then innovation index increases by 1.028 units. 2) If the company has a department of innovation or a formal process for innovation $(b=-0.525, p<0.001)$. The negative coefficient shows that if the company does not have a department or a formal process for innovation then the innovation index decreases (the variable was coded as $1=y e s, 2=n o) .3$ ) The number of employees, i.e. the size of the company $(b=0.311, p<0.001)$. The positive coefficient shows that the more employees the higher the level of innovation, or, on average, when moving from one company size category to the next the innovation index increases by 0.311 units, and 4) whether existing products, even successful ones, get reviewed from time to time $(b=-0.443$, $\mathrm{p}=0.004)$. The negative coefficient shows that if a company reviews existing products then the innovation index increases. The final Rsquare of the model is $63.9 \%$. The most important variable is "culture index" (it explains $36.8 \%$ of the variation).

In order to see if differences exist in which factors significantly affect innovation in each country, Table 5 summarizes the results in a comparative way. 
TABLE 5: Stepwise Multiple Regression for innovation: cross-country comparison

\begin{tabular}{|c|c|c|c|c|c|c|c|}
\hline Factor & Italy & England & $\begin{array}{l}\text { Greece } \\
\text { (Thes.) }\end{array}$ & $\begin{array}{l}\text { Greece } \\
\text { (Athens) }\end{array}$ & Cyprus & Lithuania & Spain \\
\hline $\begin{array}{l}\text { Company } \\
\text { Size }\end{array}$ & $\begin{array}{l}\mathrm{b}=1.883 \\
\mathrm{p}=.049 \\
\mathrm{R}^{2} \mathrm{ch} .=.367\end{array}$ & $\begin{array}{l}\mathrm{b}=.664 \\
\mathrm{p}=.009 \\
\mathrm{R}^{2} \text { ch. }=.552\end{array}$ & & $\begin{array}{l}\mathrm{b}=.444 \\
\mathrm{p}=.006 \\
\mathrm{R}^{2} \mathrm{ch} .=.174\end{array}$ & & & $\begin{array}{l}\mathrm{b}=.659 \\
\mathrm{p}<0.001 \\
\mathrm{R}^{2} \mathrm{ch} .=.591\end{array}$ \\
\hline $\begin{array}{l}\text { Department } \\
\text { or Formal } \\
\text { process }\end{array}$ & $\begin{array}{l}\mathrm{b}=-1.015 \\
\mathrm{p}=.026 \\
\mathrm{R}^{2} \mathrm{ch} .=.164\end{array}$ & & & & & $\begin{array}{l}\mathrm{b}=-.670 \\
\mathrm{p}=.005 \\
\mathrm{R}^{2} \mathrm{ch} .=.410\end{array}$ & \\
\hline $\begin{array}{l}\text { Innova- } \\
\text { tion part of } \\
\text { Strategy }\end{array}$ & & & & $\begin{array}{l}\mathrm{b}=-.928 \\
\mathrm{p}=.001 \\
\mathrm{R}^{2} \mathrm{ch} .=.234\end{array}$ & & $\begin{array}{l}\mathrm{b}=-.653 \\
\mathrm{p}=.005 \\
\mathrm{R}^{2} \mathrm{ch} .=.205\end{array}$ & \\
\hline $\begin{array}{l}\text { Culture } \\
\text { index }\end{array}$ & & & & & $\begin{array}{l}b=1.768 \\
p=.002 \\
R^{2} \text { ch. }=.766\end{array}$ & & \\
\hline $\begin{array}{l}\text { Review of } \\
\text { existing } \\
\text { products }\end{array}$ & & & & & $\begin{array}{l}\mathrm{b}=-.826 \\
\mathrm{p}=.002 \\
\mathrm{R}^{2} \mathrm{ch} .=0.064\end{array}$ & & \\
\hline $\begin{array}{l}\text { Integration } \\
\text { of social } \\
\text { trends }\end{array}$ & & & & & & $\begin{array}{l}\mathrm{b}=-.444 \\
\mathrm{p}=.019 \\
\mathrm{R}^{2} \mathrm{ch} .=.124\end{array}$ & $\begin{array}{l}\mathrm{b}=-.836 \\
\mathrm{p}=.005 \\
\mathrm{R}^{2} \mathrm{ch} .=.204\end{array}$ \\
\hline $\begin{array}{l}\text { Applied for } \\
\text { public funds }\end{array}$ & & & & & & $\begin{array}{l}\mathrm{b}=-.412 \\
\mathrm{p}=.043 \\
\mathrm{R}^{2} \mathrm{ch} .=.052\end{array}$ & \\
\hline Rsquare & 0.531 & 0.552 & N/A & 0.408 & 0.830 & 0.791 & 0.795 \\
\hline
\end{tabular}

SOURCE: Author

Overall, the results showed that different factors lead to successful/unsuccessful innovation in the various European countries confirming hypothesis 4. No significant factors were found for Greek SMEs in Thessaloniki. The size of the company is a significant factor for innovation in most of the countries. In general, the model Rsquare was satisfactory for all countries, but the best model was for Cyprus, with the corporate culture index and review of existing products explaining $83 \%$ of the variation in the innovation index. The largest number of significant factors was found for Lithuanian SMEs, namely 1) If the company has a department of innovation or a formal process for innovation, 2) If innovation is part of the strategy, 3) If the company quickly integrates social trends and 4) If the company has applied in the past for public funds.

\section{F. Current stumbling blocks of innovation}

The two major reasons blocking innovation are seen to be lack of money (42.2\%) and lack of time (40.6\%). The lack of money is strongest perceived in Italy, Greece (Thessaloniki) and Lithuania. A perception of a lack of time (most prevalent in Greece -Thessaloniki- and England) points to an underestimation of the strategic importance of innovation and creativity and confirms the existing lack of an innovation department or formal processes as to innovation. It catches the idea that 50\% of Cyprus SMEs seem to lack creative ideas and that the company's risk adverse culture is seen as the major stumbling block for innovation in Greece (Athens) and Cyprus. The reasons for previous innovation problems are quite equally scattered with high 
production costs (31.2\%) being regarded as the major problem in retrospect. The measurements for innovation success are quite equally evaluated being 'financial growth', followed by 'better market position' and 'business growth'. The relevance of resistance to change was confirmed by $36.5 \%$ of all respondents. Chi-square tests have shown significant cross-country differences in perceived resistance to change $\left(\mathrm{X}^{2}=25.5, \mathrm{p}<0.001\right)$, where it is most prevalent in Cyprus (70\%) and Greece (Thessaloniki) (54.5\%).

Since lack of money has been shown to be an obstacle in innovation, it is very important to observe funding options for European SMEs. Results have shown that only $40 \%$ of employees state that government institutions in their countries support innovation in SMEs. Significant cross-country differences $\left(\mathrm{X}^{2}=25.2, \mathrm{p}<0.001\right)$ show that the highest level of government support is perceived in England (62.5\% of respondents claimed so) and Spain (56\%), and the lowest is in Cyprus (only 6.9\% responded affirmatively). Among all SMEs the most known funding organizations are the European Union (EU) (52.7\%) and the Regional Development Agencies (41.9\%) with the knowledge level of other important fund providers being below $10 \%$ respectively. Taking the aforementioned role of capital with regard to stumbling blocks for innovation and corporate culture into account, it is most alarming that $64.3 \%$ of all employees never applied for public funds. Significant cross-country differences existed $\left(\mathrm{X}^{2}=29.6, \mathrm{p}<0.001\right)$, with Cyprus $(96.7 \%)$ and England (77.8\%) being the leaders of never having applied for public funds. Higher levels of fund applications exist, according to this study, in Greece (Athens) (60.6\%) and Spain (48.1\%). However, 61.9\% of all SMEs intend to apply in the future for funding but still a relatively high number of $38.1 \%$ do not intend to apply for funds in the future. Again, cross-country differences existed $\left(\mathrm{X}^{2}=27.8, \mathrm{p}<0.001\right)$, where the highest percentage of SMEs that do not intent to apply for funds is in Cyprus (60\%) and Italy (59.8\%). On the contrary, the highest number of funding proposals can be expected to come in the future from Greece (Thessaloniki) (90.5\%) and Lithuania (86.2\%). As very disappointing and detrimental for innovation development can be regarded the very low level of SME co-operation with universities in the six countries under examination, where $62.2 \%$ of all companies do not co-operate with universities in terms of innovation.

\section{DISCUSSION}

This study has investigated Innovation Management of SMEs in six European countries, namely the United Kingdom, Cyprus, Spain, Italy, Greece and Lithuania. The six countries under examination have different characteristics and represent both established and transitional or emerging settings.

\section{A. Contribution of the current study}

The methodology used has provided the advantage of differentiating the respective SME perceptions, key factors and levels of innovation management. This is a contribution to the field and gives new insight into the discussion regarding the catalytic role of SMEs in generating innovation as a basis for a competitive economy. More specifically, the current study conceptualized and measured two important concepts, innovation and corporate culture, thus providing a numerical framework for their examination. These new indices were the innovation index and the corporate culture index, which were hereby created specifically 
for the context of this study. Moreover, the use of the statistical method of ANCOVA made the samples from the six European countries comparable, by adjusting for the respondents' profiles and the size of the SMEs in each country, and ensuring that these individual characteristics would not affect the results. The results of the study can be considered in two levels, both an integrated European level as well as an individual country level. This is because, on one hand, the results have shown that there are no significant cross-country differences in some of the issues investigated, but on the other hand, significant country differences in terms of innovation were found.

\section{B. Main results}

Regarding the integrated level, some general conclusions can be drawn regarding innovation management of European SMEs. For example, there appears to exist a general lack of strategic approaches as to innovation, without significant cross-country differences, since there is a general lack of innovation department or formal innovation processes in the European SMEs. Moreover, results showed that no significant differences in corporate culture existed between the countries, which implies that, on average, the means of empowerment, infrastructure, incentives, training and teamwork are used to almost the same extent across all countries. No cross-country differences existed also in terms of whether companies regarded their employees as skilled in product/service development or creativity, where most companies agreed on this. The findings showed that corporate culture is regarded by the vast majority of respondents as supportive for innovation similarly in all European countries under examination. Finally, the study has shown that the two major reasons blocking innovation are seen to be lack of money and lack of time. The measurements for innovation success are quite equally evaluated being financial growth, followed by better market position and business growth. Results have shown that government institutions do not generally support innovation in SMEs. As very disappointing and detrimental for innovation development can be regarded the very low level of SME co-operation with universities in the six countries under examination.

On the other hand, our results have indicated that different strategies need to be used in each country under examination, because the levels of innovation management differ between the European countries, as well as the individual factors that affect innovation. All cross-country differences could be due to cultural or identity variations supported by Sommer et al (2009) and Rujirawanich et al (2011) as well as differences in the quality of life and overall stability and prosperity of the economy. Interestingly enough, in Greece, which was divided into two parts, many differences exist between the northern part (Thessaloniki) and the southern part (Athens). When considering the innovation index, created in this study, Cyprus has been shown to have the highest general level of innovation. In addition, considering individual components of the index, the results showed that the highest level of product/service innovations were achieved, apart from Cyprus, also in Greece (Thessaloniki) and Lithuania. However, a relatively high percentage of SMEs in Cyprus, Italy and Spain did not generate any product/service innovation nor had any social or process innovations in the last two years. Hence, in Cyprus, although on average the innovation level is high, there seems to be a gap between very innovative and less innovative companies. In total, the companies prefer more incremental rather than radical product changes. Only in Cyprus and Greece (Thessaloniki) higher levels of radical changes are apparent. In relation to companies innovating organically, 
cross-country differences existed, with England having the highest percentage of organically innovating companies and Lithuania the lowest.

Better technology, new market opportunities and customers' requirements are perceived by all companies as reasons for improvements. Minimizing waste, cost reduction and, especially, suppliers' suggestions are less considered reasons for improvements. Taking the generally accepted importance of customer orientation into account, it is astonishing that customer requirements are only considered to a very low extent as reasons for improvements in Italy, Greece (Athens) and Spain.

A very important finding of the study is that in the majority of cases, new product ideas come from owners, especially in Cyprus, Italy and Greece (Thessaloniki). There seems to be a contradiction between the awareness of the importance of customer requirements and the actual involvement of customers in the innovation and creativity process. The paramount role of the customer as well as the supplier for product idea provision is mostly acknowledged by Cyprus and England. These findings on the necessity to enhance customer and supply chain involvement in innovation is confirmed by Laforet's (2011) findings. Interestingly and encouragingly, in most of the cases across all countries 'any employee' is integrated in product/service idea selection and screening, especially in Greece (Thessaloniki), Lithuania and England. Again, customers and suppliers are less considered in this respect.

When all European countries were considered together, the results showed that the factors that significantly lead to successful innovation, in order of importance were found to be corporate culture, having a department of innovation or a formal process for innovation, the size of the company (the more employees the higher the level of innovation) and reviewing existing products from time to time, even successful ones. However, it is very important that the current study has shown that different factors lead to successful/unsuccessful innovation in the various European countries. These factors included some or even none of the above four factors, as well as additional factors, such as if innovation is part of the strategy, if the company quickly integrates social trends and if the company has applied in the past for public funds (e.g. Lithuania).

\section{Implications for practice and suggestions for future research}

The findings indicate that higher levels of product/service introductions should be pursued in Italy, Spain and Cyprus and that, in addition to product/service and incremental innovation, a stronger emphasis should be placed on social-, process- and radical innovation. Customer requirements, supplier suggestions, minimizing waste and cost reduction should be taken more intensively into account as reasons for product/service improvements. Referring to all SMEs higher levels of patent registrations are strongly suggested. The awareness of the importance of continuously tracking and integrating social trends as a major source for innovation has to be increased. Innovation should be perceived by the SMEs as a systematic and formal process with paramount strategic implications (i.e. creating innovation departments). The leadership function of empowering employees should be significantly improved by even stronger involving them in innovation development, knowledge management systems, training or teamwork. The importance of employees being skilled and trained in creativity and innovation techniques is 
confirmed by this research albeit with differentiated levels in the respective countries. Due to the strategic importance of innovation appropriate resources in terms of capital and time have to be allocated to innovation. Resistance to change is an existing phenomenon and has to be expected and planned for when intending to improve the level of innovation. Most concerning, SMEs do not feel to be supported by governments as to innovation activities. The reasons for this perception are suggested to be subject for further research. Research questions could include if this negative perception is due to lack of communication with the government, governmental and EU agencies (i.e. EU Info Centers) or if a real actual lack of support exists. SMEs should be supported for when applying for public funding and should, also, collaborate with Universities/Colleges in order to engage in concerted actions to facilitate innovation for the benefit of the companies as well the regional/national economies. SMEs might better utilize research resources of universities to mitigate the capital gap and universities might take a more prominent role in supporting SMEs as to funding information and actual procedures. Moreover, the findings imply that government development and innovation strategies should be developed in close co-operation and intensified communication with SME representatives. The findings of the study enable educators, trainers, consultants, and industrial associations to focus on SME specific factors of Innovation Management and to differentiate as to the six European countries. The existence of cross-country differences in innovation constitutes by itself an area for further research. Further research is especially suggested to take place in Central and Eastern European countries to enable a better comparison between established and transitional economic settings in Eastern Europe. The limitation of the research refers mainly to the relatively small samples per country.

\section{CONCLUSIONS}

Innovatively, the study revealed that significant differences as to innovation levels between the SMEs in the six EU countries as well as different explanatory variables for the respective level exist. The analysis has been performed both on an integrated as well as on an individual country basis and has shown that different approaches should be taken for each country. Regarding the major hurdles for higher innovation levels, most concerning are the findings that SMEs do not perceive to be sufficiently enough supported by their governments, and that a strong hesitation to apply for public funding could be observed on behalf of the SMEs. The results of the current study have shown a positive relation between innovation and corporate culture overall in the European SMEs under examination. Multiple Regression analysis led to four independent variables explaining innovation management when considering all countries together. These are, in descending order of degree of explanation, corporate culture, formal processes/innovation department, size of company and review of products. Differences in the factors that significantly affect innovation exist between the various countries, but the size of the company appears to be generally a very important factor, with a large number of employees being associated with higher levels of innovation. Apart from the four aforementioned variables that have been found significant, other variables such as whether innovation is part of the strategy, whether the company quickly integrates social trends and whether the company has applied in the past for public funds have been shown to be important for successful innovation. Relating back to the discussion in literature, the findings suggest to further test the hypothesis that the 'innovation paradox' which according to the Deloitte Touche Tohmatsu study relates to manufacturers might similarly apply for SMEs as well. Future studies might also validate a 
'customer collaboration paradox' (as mentioned by Deloitte Touche Tohmatsu) as the current study strongly points to it. Generally, Jamorog's finding is confirmed albeit the absence of a formal innovation strategy is superseded by corporate culture as the most influential explanatory factor of innovation management. In general, this study has provided new and useful information both on innovation management at a general European level and for the individual countries under examination.

\section{REFERENCES}

Antonakis, J., (2006), "Leadership: What is it and how it is implicated in strategic change", International Journal of Management Cases, 8 (4): 4-20

Aragón-Sánchez, A. \& Sánchez-Marín, G., (2005), "Strategic orientation, management characteristics, and performance: A study of Spanish SMEs", Journal of Small Business Management, 43 (3): 287-308

Baard, V. and Watts, T., Breaking the Paradox of Innovation in Small Businesses through Sustaining and Disruptive Reinvention, Australasian Accounting Business and Finance Journal, 1(2), 2007. Available at:http://ro.uow.edu.au/aabf/vol1/iss2/3

Banterle, A., Cavaliere, A., Stranieri, S. and Carraresi, L., (2009), "European Traditional Food Producers And Marketing Capabilities: An Application Of Marketing Management Process," Abstract: Applied Studies in Agribusiness and Commerce, AGRIMBA, vol. 3.

Barsh, J., Capozzi, M., \& Davidson, J., (2008). McKinsey Quarterly: http://www. strategyexecution.in/yahoo site admin/assets/docs/Innovation Execution.513527.pdf, retrieved 9.12.2009.

Berglund, K. \& Johansson, A., (2007), "Construction of Entrepreneurship: a Discourse Analysis of Academic Publications", Journal of Enterprising Communities: People and Places in the Global Economy, 1 (1): 77-102.

Bierly P., \& Chakrabarti A.K., (1996), "Generic knowledge strategies in the U.S. pharmaceutical industry", in Branzei O., \& Vertinsky I., (2006), "Strategic pathways to product innovation capabilities in SMEs", Journal of Business Venturing, 21 (1): 75-105

Blundel, R.K., \& Hingley, M., (2001), "Exploring growth in vertical inter-firm relationships", in

Boer, H., Hill, M., \& Krabbendam, K., (1990), "FMS implementation management: promise and performance", International Journal of Operations \& Production Management, 10 (1): 5-21.

Bougrain, F., \& Haudeville, B., (2002), "Innovation, collaboration and SMEs' internal research capacities", in Hotho, S. and Champion, K., (2011), "Small Businesses in the New Creative Industry: Innovation is a People Management Challenge", Management Decision, 49 (1): $29-45$

Branzei O., \& Vertinsky I., (2006), "Strategic pathways to product innovation capabilities in SMEs”, Journal of Business Venturing, 21 (1): 75-105

Burpitt, W., \& Bigoness, W., (1997), "Leadership and Innovation among Teams. The Impact of Empowerment”, Small Group Research, 28 (3): 414-423.

Busse, C. and Wallenburg, C.M., (2011), "Innovation Management of Logistics Service Providers: Foundations, Review and Research Agenda", International Journal of Physical Distribution \& Logistics Management, Vol. 41, Iss: 2, pp. 187-218 
Boyett, I., (1997), “The Public Sector Entrepreneur- a Definition”, International Journal of Entrepreneurial Behavior \& Research, 3 (2): 77-92.

Choueke, R., \& Armstrong, R., (1998), "The learning organization in small and mediumsized enterprises: a destination or a journey", International Journal of Behaviour and Research, 4 (2): 129-140.

Christensen, K.S. (2006), "Innovativeness: the challenge of being acquired", Management Decision, 44 (9): 1161-1182

Cohen, W.M., \& Klepper, S., (1996), "Firm size and the nature of innovation within industries: the case of process and product R\&D", in Forsman, H. and Rantanen, H., (2011) "Small manufacturing and service enterprises as innovators: a comparison by size", European Journal of Innovation Management, Vol. 14 Iss: 1, pp.27 - 50

Cooney, T.M., and O'Connor, A. (1996), "A survey of perceived barriers to innovation across countries in Demirbas, D., Hussain, J.G., and Matlay, H. (2011), "Owner-manager's perception of barriers to innovation: empirical evidence from Turkish SMEs", Journal of Small Business and Entreprise, 18 (4):764-780

Crick, D., (2011), "Enterprising Individuals and Entrepreneurial Learning: A Longitudinal Case History in the UK Tourism Sector", International Journal of Entrepreneurial Behavior \& Research, 17 (2): 203-218

Dampanpour, F., (1991), "Organization Innovation: a meta-analysis of effects of determinants and moderators", Academy of Management Journal, 34 (2): 555-590.

Darroch, J., \& McNaughton, R., (2002), "Examining the link between knowledge management practices and types of Innovation", Journal of Intellectual Capital, 3 (3): 210-222.

De Jong J.P.J. and Den Hartog, D.N. (2007), "How leaders influence employees' behavior", European Journal of Innovation Management, 10 (1): 41-64

Delahaye, B. (2005), "Knowledge management in an SME", Hotho, S. and Champion, K., (2011), "Small Businesses in the New Creative Industry: Innovation is a People Management Challenge", Management Decision, 49 (1): 29-45

Deloitte, Touche, Tohmatsu, (2003), 'The Challenge of Complexity in Global Manufacturing- Critical Trends in Supply Chain Management- available at: http://www. deloitte.com/assets/Dcom-Shared\%20Assets/Documents/SupplyChainSurvey(1).pdf, accessed at 2. June 2012

Demirbas, D., Hussain, H.M. \& Matlay, H., (2011), “Owner-Manager's Perceptions of Barriers to Innovation: Empirical Evidence from Turkish SMEs", Journal of Small Business and Enterprise Development, 18 (4): 764-780

Denton, D., (1999), "Gaining Competitiveness through Innovation”. European Journal of Innovation Management, 2 (2): 82-85.

Dougherty, D. and Hardy, C. (1996), "Sustained product innovation in large, mature organizations: overcoming innovation-to-organisation problems", Academy of Management Journal, 39 (5):1120-1153

Du Plessis, M., (2007), “The Role of Knowledge Management in Innovation”, Journal of Knowledge Management, 11 (4): 20-29.

Elonnen, R., Blomqvist, K., and Puumalainen, K. (2008), “The role of trust in organizational innovativeness", European Journal of Innovation management, 11 (2): 160-181

EU (2005), Europa- das Portal der Europäischen Union (12.07.2005): Beobachtungsnetz der Europäischen KMU (2003): Internationalisierung von KMU, http://europa.eu.int/

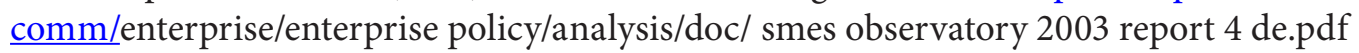


(24.07.2005): 1- 73, retrieved 20.03.2011

European Union (2011), "SMEs want patent protection at heart of 'EU Innovation Act”: http://www.euractiv.com/en/enterprise-jobs/smes-want-patent-protection-heart-euinnovation-act/article-185195, retrieved 20.03.2011.

Forsman, H., (2008), "Business development success in SMEs", in Forsman, H. and Rantanen,H., (2011) "Small manufacturing and service enterprises as innovators: a comparison by size", European Journal of Innovation Management, 14 (1): 27 - 50

Forsman, H. and Rantanen,H., (2011) "Small manufacturing and service enterprises as innovators: a comparison by size", European Journal of Innovation Management, 14 (1): 27 - 50

Franke, M., (2007), "Innovation: the Winning Formula to Regain Profitability in Aviation", Journal of Air Transport Management, 13 (1): 23-30

Freel M., (2000) "Barriers to Product Innovation in Small Manufacturing Firms", in McAdam, Moffett, S., Hazlett, S.A. and Shevlin, M., (2010), "Developing a Model of Innovation Implementation for UK SMEs: A Path Analysis and Explanatory Case Analysis", International Small Business Journal, 28 (3): 195-214

Geroski, P.A., Machin, S., Van Reenen, J.M., (1993), “ The Profitability of Innovating Firms", RAND Journal of Economics, 24, (2): 198-211

Hannula, M., Rantanen, H. (2000), "Obstacles restraining productivity improvement in the Finnish SME sector", in Forsman, H. and Rantanen,H., (2011) "Small manufacturing and service enterprises as innovators: a comparison by size", European Journal of Innovation Management, 14 (1): 27 - 50

Helfat C., Raubitschek R., (2000), "Product sequencing: co-evolution of knowledge, capabilities and products", in Branzei O., \& Vertinsky I., (2006), "Strategic pathways to product innovation capabilities in SMEs", Journal of Business Venturing, 21 (1): 75-105

Henderson, J. (2002) in Oke, A. Burke, G. and Myers, G. (2007), "Innovation types and performance in growing UK SMEs", International Journal of Operations \& Production Management, 27 (7): 735-753

Hotho, S. and Champion, K., (2011), "Small Businesses in the New Creative Industry: Innovation is a People Management Challenge", Management Decision, 49 (1): 29-45

Hughes A., Mina A., (2010), "The impact of the patent system on SMEs", Centre for Business Research, University of Cambridge: 411

Hurley, R., \& Hult, G. (1998), "Innovation, market orientation, and organizational learning: an integration and empirical examination", Journal of Marketing, 62, 42-52.

InnoSupport: Supporting Innovation in SMEs. Available at: http://www.innovation.lv/ ino2/publications/sme manual en.pdf. Accessed: 25th March, 2011.

Jamrog, J.J. (2006), in Fortuin, F.T.J.M. and Omta, S.W.F. (2009), "Innovation drivers and barriers in food processing", British Food Journal, 111 (8):839-851

Jantunen, A. (2005), "Knowledge-processing capabilities and innovative performance: an empirical study", European Journal of Innovation Management, 8 (3): 336-349

Jones, O. and Tilley, F., (2003), Competitive Advantage in SMEs, John Wiley \& Sons Ltd. Chichester, UK

Kaufmann, H.R., (2008), "Internationalization of SMEs in the Rhine Valley: Globalization Entering the Rhine Valley”, In: Dana, L./Han, M./Ratten, V./Welpe, I. A Theory of Internationalization for European Entrepreneurship, Edward Elgar: 386-410

Kaufmann, H. R. (2009), “The Contribution of Entrepreneurship to Society”, International Journal of Entrepreneurship and Small Business, 7 (1): 59-72 
Kaufmann, H.R., and Durst, S. (2008), “The Development of an Inter Regions Brand- a Case Study of the Principality of Liechtenstein", EuroMed Journal of Business, 3 (1), 38-62

Kaufmann, H.R., Mewald, A. and Sanchez Bengoa, D., (2012), "Social Entrepreneurship and Cross-Sectoral Parnterships in CEE Countries", in Burger-Helmchen, T. (2012), Entrepreneurship- Gender, Geographies and Social Context-, InTech, Croatia, ISBN 978-95351-0206-9

Keegan, J., O’Connor, A., Cooney, T., Ylinenpaa, H., Barth, H., Vesalainen, J., Pihkala, T., Deschoolmeester, D., Debbaut, A. (1997), Facing the challenge- towards a better understanding of barriers to innovation in Irish, Swedish, Finnish and Belgium SMEs in Demirbas, D., Hussain, J.G., and Matlay, H. (2011), “Owner-manager's perception of barriers to innovation: empirical evidence from Turkish SMEs”, Journal of Small Business and Entreprise, 18 (4):764-780

Keizer, J.A., Dijkstra, L. \& Halman, J.I.M., (2002), “Explaining Innovative Efforts of SMEs. An Exploratory Survey among SMEs in the Mechanical and Electrical Engineering Sector in The Netherlands", in Hotho, S. and Champion, K., (2011), "Small Businesses in the New Creative Industry: Innovation is a People Management Challenge", Management Decision, 49 (1): 29-45

Khazanchi, S., Lewis, M.W. \& Boyer, K.K., (2007), "Innovation-Supportive Culture: The Impact of Organizational Values on Process Innovation”, in Busse, C. and Wallenburg, C.M., (2011), "Innovation Management of Logistics Service Providers: Foundations, Review and Research Agenda”, International Journal of Physical Distribution \& Logistics Management, Vol. 41, Iss: 2, pp. 187-218

Klapper, R., (2004), "Government goals and entrepreneurship education- an investigation at a Grande Ecole in France”, Education and Training, 46 (3), 127-137

Koh, H.C., (1996), “Testing hypotheses of entrepreneurial characteristics", Journal of Managerial Psychology, 11 (3), 12-25

Kotter J. and Heskett J., (1992), Corporate culture and performance. (N.Y.: Free Press)

Laforet, S. (2011), "A Framework of Organisational Innovation and Outcomes in SMEs", International Journal of Entrepreneurial Behavior \& Research, 17 (4): 380-408

Lange, T., Ottens, M., Taylor, A. (2000), "SMEs and barriers to skills development: a Scottish perspective", in Hotho, S. and Champion, K., (2011), "Small Businesses in the New Creative Industry: Innovation is a People Management Challenge”, Management Decision, 49 (1): $29-45$

Leiponen, A., (2000), “Competencies, Innovation and Profitability of Firms”, Economics of Innovation and New Technology, 9 (1): 1-24

Lindner, J.C., (2006), "Does innovation drive profitable growth? New Metrics for a Complex Picture", Journal of Business Strategy, 27 (5): 38-44

Malach-Pines, A., Levy, H., \& Utasi, A., (2005), "Entrepreneurs as cultural heroes", Journal of Managerial Psychology, 20 (6), 541-555

Martin, R.L, (n/y), "A Study on the Factors of Regional Competitiveness", available at: http://ec.europa.eu/regional policy/sources/docgener/studies/pdf/3cr/competitiveness.pdf; accessed at 16 May 2012

McAdam, R., McConvery, T. \& Armstrong, G. (2004), "Barriers to innovation within small firms in a peripheral location", International Journal of Entrepreneurial Behaviour \& Research, 10 (3): 206-21

McAdam,R., Keogh,W., Reid, S.R., \& Mitchell, N., (2007), "Implementing innovation 
management in manufacturing SMEs: a longitudinal study", Journal of Small Business and Enterprise Development, 14 (3), 385-403

McAdam, Moffett, S., Hazlett, S.A. and Shevlin, M., (2010), "Developing a Model of Innovation Implementation for UK SMEs: A Path Analysis and Explanatory Case Analysis", International Small Business Journal, 28 (3), 195-214

McGrath, R.G., Ming-Hone, T. (1996), "Innovation, competitive advantage and rent: a model and test", in Busse, C. and Wallenburg, C.M., (2011), "Innovation Management of Logistics Service Providers: Foundations, Review and Research Agenda", International Journal of Physical Distribution \& Logistics Management, 41 (2): 187-218

Morcillo P., (1997), Dirección estratégica de la tecnología e innovación, (Madrid: Civitas)

Morcillo, P., Rodriguez-Anton, J.M., Rubio, L., (2006), "Corporate Culture and Innovation: In Search of the Perfect Relationship", International Journal of Innovation and Learning, 3 (4): 349-357

Morris, M.H., and Sexton, D.L., (1996), in Chowdhury, M.S. (2007), "Overcoming entrepreneurship development constraints: the case of Bangladesh", Journal of Enterprising Communities: People and Places in the Global Economy, 1 (3): 240-251

Neira, O.C., Lindman, M.T., \& Fernandez, J.M. (2009), "Innovation and performance in SME furniture industries: an international cooperative case study", Journal of Marketing Intelligence and Planning, 27 (2), 216-232

NESTA (2008a), "Unlocking the potential of innovative firms", Hotho, S. and Champion, K., (2011), "Small Businesses in the New Creative Industry: Innovation is a People Management Challenge", Management Decision, 49 (1): 29-45

NESTA (2008b), Raise the Game: The Competitiveness of the UK's Games Development Sector and the Impact of Governmental Support in Other Countries, in Hotho, S. and Champion, K., (2011), "Small Businesses in the New Creative Industry: Innovation is a People Management Challenge", Management Decision, 49 (1): 29-45

NESTA (2009), It's Time to Play: A Survey on the Impact of a Tax Credit for Cultural Video Games in the UK Development Sector, in Hotho, S. and Champion, K., (2011), "Small Businesses in the New Creative Industry: Innovation is a People Management Challenge”, Management Decision, 49 (1): 29-45

Nicholas, J., Ledwith, A., and Perks, H. (2011), "New product development best practice in SME and large organizations: theory vs practice", European Journal of Innovation Management 14 (2):227-251

O'Dwyer, M., Gilmore, A., \& Carson, D., (2009), "Innovative Marketing in SMEs", European Journal of Marketing, 43 (1/2), 46-61

Oke, A., Burke, G., \& Myers, A., (2007), "Innovation types and performance in growing UK SMEs", International Journal of Operation and Production Management, 27 (7), 735-753.

O’Regan, N., Ghobadian, A., Sims, M., (2005), "Fast tracking innovation in manufacturing SMEs", Technovation, 20: 1-11

Ostgaard T., Birley S., (1994), "Personal networks and firm competitive strategy: a strategic or coincidental match?" in Branzei O., \& Vertinsky I., (2006), "Strategic pathways to product innovation capabilities in SMEs", Journal of Business Venturing, 21 (1): 75-105

Peet S., Brindley C. \& Ritchie B., (2002), "The European Commission and SME support mechanisms for e-business", European Business Review, 14 (5): 335-341

Prajogo, D., \& Sohal, A. (2003), "The relationship between TQM practices, quality performance, and innovation performance", International Journal of Quality \& Reliability 
Management, 20 (8): 901-918

Radzeviciene, D., (2008), "Developing Small and Medium Enterprises Using Knowledge Management Framework: A Case Study of Lithuania”, Aslib Proceedings, 60 (6): 672-685

Salavou, H., \& Avlonitis, G., (2008), "Product Innovation and Performance: a Focus on SMEs", Management Decision, 46 (7): 969-985

Rujirawanich, P., Addison, R., Smallman, C., (2011), “The Effects of Cultural Factors on Innovation in a Thai SME”, Managerial Research Review, 34 (12): 1264-1279

Rothwell, R. (1989), "Small firms, innovation and industrial change", in Hotho, S. and Champion, K., (2011), "Small Businesses in the New Creative Industry: Innovation is a People Management Challenge”, Management Decision, 49 (1): 29-45

Segarra-Blasco, A., Garcia-Quevedo, J., Teruel-Carrizosa, M. (2008), “Barriers to innovationand public policy in Catalonia” in Demirbas, D., Hussain, J.G., and Matlay, H. (2011), “Owner-manager's perception of barriers to innovation: empirical evidence from Turkish SMEs", Journal of Small Business and Entreprise, 18 (4):764-780

Sommer, L., Kaufmann, H.R., Durst, S., and Haug, M., (2009), “The impact of decision Maker's identity on SME internationalization- Do Origins Matter", International Journal of Business and Globalization, 5 (1): 90-118

Scozzi, B., Garavelli, C., Crowston, K. (2005), "Methods for modeling and supporting innovation process in SMEs", in Forsman, H. and Rantanen,H., (2011) "Small manufacturing and service enterprises as innovators: a comparison by size", European Journal of Innovation Management, 14 (1): 27 - 50

Shaw, E., O’Loughlin, A., \& McFadzean, E. (2005), "Corporate Entrepreneurship and Innovation part 2: a Role- and Process-Based Approach", European Journal of Innovation Management, 8 (4): 393-408

The European Central Bank, "Economic Policy", available at: http://www.ecb.int/mopo/ eaec/ecopolicy/html/index.en.html, accessed at 16 May 2012

Teece J., Pisano G., Shuen A., (1997), "Dynamic capabilities and strategic management”, Strategic Management Journal, 18 (7): 509-533

Tidd, J. (2001), "Innovation management in context: environment, organization and performance", International Journal of Management Review, 3 (3): 169-83

Tidd J, Bessant J, and Pavitt K, (2004), Managing Innovation: Integrating Technological, Market and Organisational Change in McAdam, Moffett, S., Hazlett, S.A. and Shevlin, M., (2010), "Developing a Model of Innovation Implementation for UK SMEs: A Path Analysis and Explanatory Case Analysis”, International Small Business Journal, 28 (3): 195-214

Vossen, R., ( 1999), "Relative strengths and weaknesses of small firms in innovation", in McAdam, Moffett, S., Hazlett, S.A. and Shevlin, M., (2010), "Developing a Model of Innovation Implementation for UK SMEs: A Path Analysis and Explanatory Case Analysis”, International Small Business Journal, 28 (3): 195-214

Weerawardena, J. (2003), "Exploring the role of market learning capability in competitive strategy", European Journal of Marketing, 37 (3/4): 407-429.

Winter S., Szulanski G., (2001), "Replication as strategy", in Branzei O., \& Vertinsky I., (2006), "Strategic pathways to product innovation capabilities in SMEs", Journal of Business Venturing, 21 (1): 75-105

Wolff, J., \& Pett, T. (2006), "Small-firm performance: modeling the role of product and process improvements”, Journal of Small Business Management, 44 (2): 268-284

Wyer, P., Mason, J., \& Theodorakopoulos, N. (2000), "Small business development and 
Economic Research - Ekonomska istraživanja, Vol. 25 (2012) No. 2 (333-360)

the learning organisation", International Journal of Entrepreneurial Behaviour and Research, 6 (4), 239-259

Zahra, S.A., George G., (2002), "Absorptive capacity: a review, reconceptualization, and extension", in Branzei O., \& Vertinsky I., (2006), "Strategic pathways to product innovation capabilities in SMEs”, Journal of Business Venturing, 21 (1): 75-105 
Sažetak

Cilj rada je doprinos raspravi o katalitičkoj ulozi malih i srednjih poduzeća u stvaranju inovacija kao osnove za konkurentnu ekonomiju. Rad je usredotočen na šest europskih zemalja, kako razvijenih tako i onih u tranziciji (Ujedinjeno Kraljevstvo, Cipar, Španjolska, Italija, Grčka $i$ Litva). Korištene statističke metode uključuju ANCOVA, višestruku regresijsku analizu $i$ hikvadrat testove. Dani su čimbenici koji objašnjavaju stupnjeve inovacije. Stvoreni su indeksi inovacija $i$ korporativne kulture za koje se ispostavilo da su korelirani. Prikazane su četiri varijable kako bi se objasnilo upravljanje inovacijama u šest zemalja: korporativna kultura, odjel formalnih procesa/inovacija, veličina poduzeća i pregled proizvoda. Na taj su način za tih šest zemalja diferencirane percepcija malih i srednjih poduzeća, ključni čimbenici i razine upravljanja inovacijama. Takav je sveobuhvatni diferencirani pristup inovativan doprinos ovom području.

Ključne riječi: Europska mala i srednja poduzeća, upravljanje inovacijama, korporativna kultura, indeks inovacije, ANCOVA, višestruka regresija. 
Economic Research - Ekonomska istraživanja, Vol. 25 (2012) No. 2 (333-360) 